УДК 378.018 .43

https://doi.org/10.52058/2786-4952-2022-2(7)-597-609

Сас Кристина Григорівна студентка, Херсонський державний університет, вул. Університетська, 27, м. Херсон, 73000, тел.: (0552) 32-67-68

Шерман Михайло Ісаакович доктор педагогічних наук, професор, кафедра комп'ютерних наук та програмної інженерії, Херсонський державний університет, вул. Університетська, 27, м. Херсон, 73000, тел.: (0552) 32-67-68, https://orcid.org/0000-0001-5120-620X

Гнсдкова Ольга Олександрівна кандидат педагогічних наук, доцент, кафедра комп'ютерних наук та програмної інженерії, Херсонський державний університет, вул. Університетська, 27, м. Херсон, 73000, тел.: (0552) 32-67-68, https://orcid.org/0000-0001-5194-2194

\title{
РОЗРОБЛЕННЯ ІНТЕРФЕЙСУ ІНФОРМАЦИЙНОЇ СИСТЕМИ НАВЧАЛЬНОГО ПРИЗНАЧЕННЯ «СТАТИСТИЧНІ МЕТОДИ У СОЦІОЛОГІЧНИХ ДОСЛІДЖЕННЯХ»
}

Анотація. Сучасне суспільство характеризується стрімкими змінами в соціальній структурі, що підсилюється взаємозв'язком 3 інформаційними технологіями. Інтенсивне застосування в соціально-психологічних науках статистичних методів пов'язано насамперед з природою поведінки людини. У 21 столітті та в умовах всесвітньої пандемії широке розповсюдження набуває електронне навчання. Інтерес населення до електронного навчання настільки посилився, що класичні навчальні заклади стали розглядати включення онлайнкурсів в свої програми в якості обов'язкового компонента. Різноманітні теоретичні і практичні онлайн-курси стають все більш і більш популярними серед населення. Розвиток електронного навчання вимагає, щоб освітні установи володіли сучасним комунікаційним обладнанням, необхідним для впровадження нових освітніх програм i забезпечення їх реалізації; кваліфікованими фахівцями i викладачами, що забезпечує безперебійне функціонування обладнання, необхідного для впровадження нових освітніх програм. Отже, повинно бути створено інформаційно-освітнє середовище електронного навчання, що включає комплекс цифрових освітніх ресурсів, сукупність інформаційних та телекомунікаційних технологій, комунікаційне обладнання, швидкісні телекомунікації, інтерактивні технології, програмноапаратну платформу, систему сучасних педагогічних технологій, які забезпечують навчання в інформаційно-освітньому середовищі. Важливе місце у забезпеченні якісного, коректного та зручного використання створеного електронного курсу відводиться розробленню інтерфейсу, що сприятиме 
кращому опануванню навчальним матеріалом здобувачами вищої освіти та їхньої адаптації до умов електронного навчання. У представленій статті наведено відомості щодо проектування, моделювання, розроблення прототипу інтерфейсу авторської інформаційної системи навчального призначення «Статистичні методи у соціологічних дослідженнях».

Ключові слова: інтерфейс, прототип, інформаційно-комунікаційні технології, інформаційна система, статистичні методи, дистанційне навчання.

Sas Kristina Hryhorievna Student, Kherson State University, University St., 27, Kherson, 73000, tel.: (0552) 32-67-68

Sherman Mykhailo Isaakovych Doctor of Pedagogical Sciences, Professor, Department of Computer Science and Software Engineering, Kherson State University, University St., 27, Kherson, 73000, tel.: (0552) 32-67-68, https://orcid.org/0000-0001-5120-620X

Hniedkova Olha Oleksandrovna $\mathrm{PhD}$ in Pedagogical Sciences, Associate Professor, Department of Computer Science and Software Engineering, Kherson State University, University St., 27, Kherson, 73000, tel.: (0552) 32-67-68, https://orcid.org/0000-0001-5194-2194

\section{INTERFACE DEVELOPMENT OF THE INFORMATION SYSTEM OF EDUCATIONAL PURPOSE "STATISTICAL METHODS IN SOCIOLOGICAL RESEARCHES"}

Abstract. Modern society is characterized by rapid changes in the social structure. It is reinforced by the relationship with information technology. Intensive use of statistical methods in the social and psychological sciences is primarily related to human behavior nature. In the $21^{\text {st }}$ century and in the context of the global pandemic, e-learning is becoming widespread. The interest in e-learning has increased so much that classical educational institutions include the online courses in the curricula as a mandatory component. A variety of theoretical and practical online courses are becoming more and more popular. The e-learning development requires the modern communication equipment needed to implement new curricula and ensure their implementation; qualified specialists and teachers necessary for the implementation of new curricula and ensuring their implementation.

Therefore, an information and educational environment for e-learning should be developed, which includes a set of digital educational resources, a set of information and telecommunications technologies, communication equipment, high-speed telecommunications, interactive technologies, software and hardware platform, system of modern pedagogical technologies.

An important place in quality ensuring, correct and convenient use of the ecourse is given to the interface development. It will promote better mastery of 
educational material by higher education students and their adaptation to the elearning conditions.

The presented article provides information on the design, modeling, and interface prototype development of the author's information system for educational purposes "Statistical methods in sociological researches".

Keywords: interface, prototype, information and communication technologies, information system, statistical methods, distance learning.

Постановка проблеми. Сучасне суспільство характеризується стрімкими змінами в соціальній структурі, що підсилюється взаємозв'язком 3 інформаційними технологіями. Інтенсивне застосування в соціальнопсихологічних науках статистичних методів пов'язано насамперед з природою поведінки людини. На початку XXI ст. електронне навчання стало активно впроваджуватися в традиційне навчання в самих різних організаційних формах: як підтримка традиційного очного i заочного навчання або як новий рівень розвитку дистанційного навчання за програмами додаткової професійної освіти, підвищення кваліфікації викладачів вузів, довузівської підготовки, першого і другого вищої освіти, магістратури. У всіх розвинених країнах електронна освіта вже займає власну нішу в навчальній сфері.

Актуальність нашого дослідження щодо ідеї використання інформаційних систем навчального призначення полягає в швидкості подачі інформації широкому колу осіб. Тому головне призначення нашої системи - це надання інформації. Незважаючи на існування інших способів передачі даних, величезна кількість людей вибирають саме цей спосіб, як найбільш ефективний.

Аналіз останніх досліджень i публікацій. Проблеми математичної підготовки студентів різного професійного спрямування досить широко висвітлені у працях видатних математиків і педагогів. Це роботи $Є$. Вентцель, В. Глушкова, Б. Гнеденка, Л. Кудрявцева, О. Самарського, М. Шкіля. Також заслуговують уваги науково-методичні дослідження Г. Біляніна, В. Венікова, Ю. Галайко, Г. Дудки, В. Клочко, О. Красножон, Т. Крилової, Л. Нічуговської, В. Петрук, М. Потоцького, Л. Пуханової, С. Ракова, Н. Самарчук, А. Столяра, Ю. Триуса, О. Фомкіної. Опис розробки інтерфейсу інформаційної системи навчального призначення визначали у своїх роботах такі учені Л. Калашнікова, Л. Черноус, М. Шерман, Н.Балик, В.Мандзюк. Незважаючи на велику кількість наукових публікацій, присвячених проблемам математичної підготовки студентів різних напрямків підготовки, грунтовного дослідження в галузі методики викладання математичних дисциплін соціологам українськими дослідниками не проводилось.

Метою статті $\epsilon$ розробка інтерфейсу інформаційної системи навчального призначення «Статистичні методи у соціологічних дослідженнях». Система розрахована на студентів технічних спеціальностей, соціологів, маркетологів, економістів, фахівців зі стратегічного планування, викладачів вишів, аналітиків, епідеміологів та на всіх осіб, які бажають ефективно вивчати статистичні методи. Також присвячена викладенню основ математичної статистики. 
Журнал«Герспективитаінновації наукиљ

(Серія«Гедагогіка», Серія«Гцихологія», Серія«Медицинв»

№2(7) 2022

Виклад основного матеріалу. Питання викладання математичних дисциплін дуже актуальне для гуманітарних напрямів вищої освіти, і полягає вона в тому, що студенти гуманітарії, зокрема соціологи, не бачать необхідності у вивченні математики. Вони як би «не сприймають» дисципліни математичного циклу, причому їхні аргументи зводяться до того, що вони як гуманітарії мають зовсім інші інтереси і здібності, які роблять важким засвоєння математичних фактів, та й вважають, що знання математики не буде затребувана в їх майбутньої професійної діяльності. Труднощі, що виникають у студентів соціологів при вивченні математики, обумовлені недостатньою базовою підготовкою зі шкільної математики, відсутністю у багатьох студентів навичок систематичної самостійної роботи. Для викладачів складність навчання математики студентів гуманітарних спеціальностей, таких, як, наприклад, «Соціологія», пов'язана 3 неуспішністю студентів 3 математики або відставанням на якомусь проміжному етапі процесу навчання, 3 відсутністю доступних i переконливих прикладів застосування математики в майбутній професійній діяльності. Все це не кращим чином позначається на якості математичної підготовки майбутніх фахівців соціологів, що в свою чергу не відповідає запиту суспільства, якому сьогодні потрібні творчі, висококомпетентні, соціально активні особистості, здатні до саморозвитку, самоосвіти і професійного росту.

Слід зазначити, математика сьогодні все здебільшого проникає у соціологію. Соціологи при проведенні соціологічних досліджень все частіше використовують математичну мову, математичний апарат. Математичні знання потрібні студентам соціологам ще й для того, щоб, навчаючись на старших курсах, оволодіти спеціальними дисциплінами. Наприклад, для вивчення таких вузівських дисциплін як «Аналіз соціологічних даних», «Моделювання соціальних процесів», «Вимірювання в соціології» студентам необхідні знання вищої математики. Очевидно, що математика відіграє чималу роль, як в подальшій освіті студентів, так і в майбутній професійній діяльності. Якість математичної підготовки майбутніх соціологів $\epsilon$ предметом пильної уваги фахівців, що займаються проблемами соціологічної освіти [Error! Reference source not found.].

Для розробки інтерфейсу інформаційної системи навчального призначення необхідно детально продумати структуру інтерфейсу. Перш за все, структура інтерфейсу - це організація і оформлення інформації таким чином, щоб відвідувач міг швидко розібратися 3 інтерфейсом і відрізнити головне від другорядного. Структура інтерфейсу являє собою його план. У свою чергу, вона поділяється на внутрішню і зовнішню. Внутрішня структура сайту визначає, 3 яких сторінок буде складатися сайт i порядок їх вкладеності (категоріяпідкатегорія-сутність) [18].

У той час як зовнішня структура сайту передбачає вид окремих сторінок в залежності від розміщення на них інформації. Тобто зовнішня структура - це якраз і є структура сторінки сайту. 
Правильна структура сайту:

- спрощує і підвищує якість взаємодії користувача з сайтом, покращує поведінковий досвід;

- впливає на ранжування і позиції сайту у видачі;

- дає можливість охоплювати більшу кількість запитів;

- зменшує кількість технічних помилок на сайті (дозволить уникнути великої кількості дублів сторінок, що дозволить заощадити час і гроші на просування);

- впливає на відображення додаткових посилань на сайт в сніппеті («анонсі» сторінки в пошуку, який мотивує відвідування сайту відвідувачем).

Розглянемо два основних типи структури сайтів:

1. Лінійна структура сайту

Структура простого сайту припускає наявність головної сторінки («Головна») i декількох внутрішніх веб-сторінок другого рівня (приклад: «Головна/веб-сторінка1» $\mathrm{i}$ «Головна/веб-сторінка2»).

2. Деревоподібна структура сайту

Має на увазі наявність 3 і більше рівнів вкладеності (приклад: «Головна/Учбові матеріали/Загальне уявлення про математичну статистику» $\mathrm{i}$ «Головна/Таблиці, математичні формули/Таблиця інтегралів»). Кожна гілка в такій структурі може мати різну глибину вкладеності (приклад: перша гілка «Головна/Книги», друга - «Головна/Про сайт/Контакти», третя - «Головна Учбові матеріали/Загальне уявлення про математичну статистику/Загальне представлення про соціологічні шкали»).

Для моделювання інтерфейсу нашої системи ми використовували деревоподібну структуру. Отримані сценарії користувачів на попередньому етапі, лягли в основу структури інтерфейсу. На цьому етапі стає відомою кількість екранів, їх короткий зміст і положення в загальній структурі. Структуру інтерфейсу системи ми створювали в додатку miMind, результат представлений на рис.1. 
Журнал«Герспективита іновациї наукиљ (Серія«ГЕдагогіка», Серія«ГТихологія», Серія«Медицина» №2(7) 2022

\section{OmiMind}

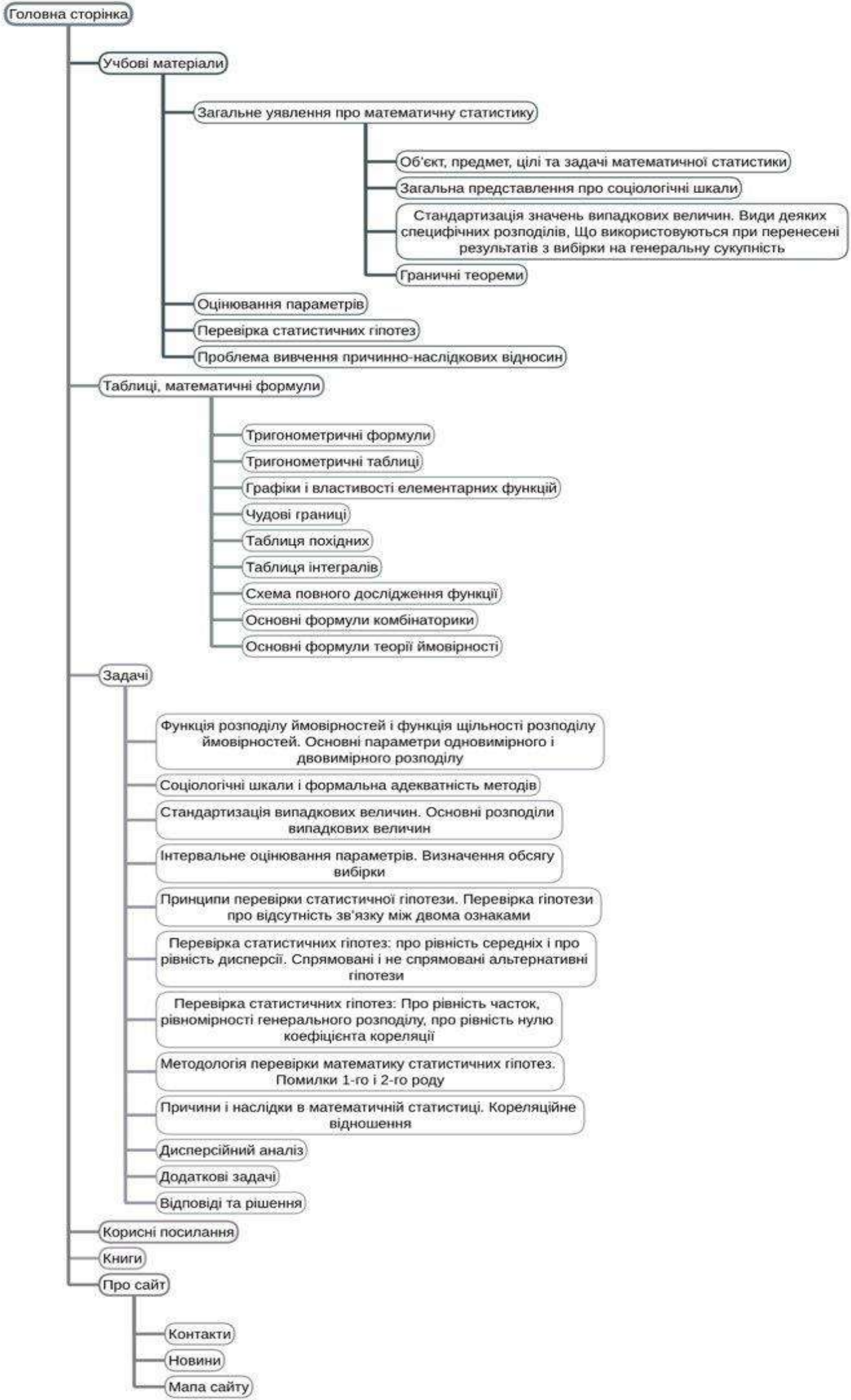

Puc.1. Структуру інтерфейсу системи

Проєктування прототипу інтерфейсу 
Прототип - це робоча модель, побудована для розробки та перевірки дизайнерських ідей. При розробці веб- та програмного інтерфейсу прототипи можуть бути використані для вивчення вмісту, естетики та прийомів взаємодії 3 точки зору дизайнерів, клієнтів та користувачів. Спеціалісти з юзабіліті часто тестують прототипи, спостерігаючи за користувачами, які виконують завдання, типові для використання продукту за призначенням. Збираючи дані про помилки та коментарі користувачів, дизайнери та спеціалісти з юзабіліті можуть виявити проблеми юзабіліті на ранній стадії проєктування, перш ніж значні ресурси будуть вкладені в недосконалі конструкції.

Юзабіліті - зручність і простота використання сайту для цілей відвідувачів. У юзабіліті входить структура сайту, меню, онлайн-заявки, калькулятори тощо [13].

Прототипування - це створення ескізу, схеми чи макету інтерфейсу. Прототипи дозволяють заощадити гроші та час, які були б витрачені на розробку ще неперевірених рішень.

Прототипування потрібно для:

- виявлення та написання вимог до функціонала, інтерфейсу, веб-сайту;

- управління очікуваннями замовника;

- ілюстрування user stories або use cases для того, щоб вони стали більш зрозумілими;

- затвердження основних блоків і розташування з замовником;

- передача вимог дизайнеру;

- тестування розташування блоків, кнопок, та валідація ідей.

Слід зазначити, що прототипування сторінок - це продумування змісту i розташування важливих елементів сторінки. Таких як:

- навігація;

- контактна інформація;

- СТА-елементи;

- контент;

- логотипи;

- хедер (шапка сайту);

- футер (підвал) тощо.

Затвердження смислових блоків на сторінці на етапі прототипування допомагає істотно заощадити час і гроші на розробку та позбавляє від помилок на початковому етапі. «Часто веб-розробники та розробники програмного забезпечення виготовляють зразки більш ніж однією технікою, наближаючись до кінцевих методів виробництва по мірі завершення проекту [6].

Прототипи більше схожі на кінцевий продукт є "високоточними", тоді як менш схожі - “низько точними”. Прототип із високою точністю часто виготовляється тими самими методами як кінцевий продукт i, отже, має ті самі техніки взаємодії та зовнішній вигляд, що й кінцевий продукт, але є більш дорогим та трудомістким у виробництві, ніж прототип з низькою точністю» [7].

Для розробки прототипу інтерфейсу було обрано середовище розробки Figma. Figma - крос-платформений онлайн-сервіс для дизайнерів інтерфейсів і 
Журнал«Герспективитаінновації наукиљ

(Серія«ГЕдагогіка», Серія«ГТихологія», Серія«Медицинв»

№2(7) 2022

веброзробників. Сервіс дозволяє розробляти інтерфейси в онлайн режимі [9]. У Figma $\epsilon$ дві ознаки: доступ до макетів через браузер і спільна робота над документами.

Даний сервіс допомагає створювати:

- інтерактивні прототипи сайтів і мобільних додатків;

- векторні ілюстрації;

- елементи інтерфейсу - іконки, кнопки, меню, вікна, форми зворотного зв'язку.

У Figma всі документи зберігаються в хмарному сховищі. Завдяки цьому в редакторі можна відкривати макети за посиланням, без необхідного скачування та працювати над ними колективно. Можна заходити в Figma через браузер або ж завантажити програму на комп'ютер. Вона сумісна як з Windows, так і з Мас. Якщо у вас відсутній доступ до інтернету, у десктопній версії ви маєте можливість працювати офлайн, а коли з'явиться інтернет, то зміни синхронізуються [11].

Для створення прототипа на практиці був розроблений і анімований макет (рис. 2 та рис. 3) для сайту. У випадку з сайтом, використовувалися найпростіші фігури. При натисканні на круглі елементи зліва, відбувався «перехід» сторінок.

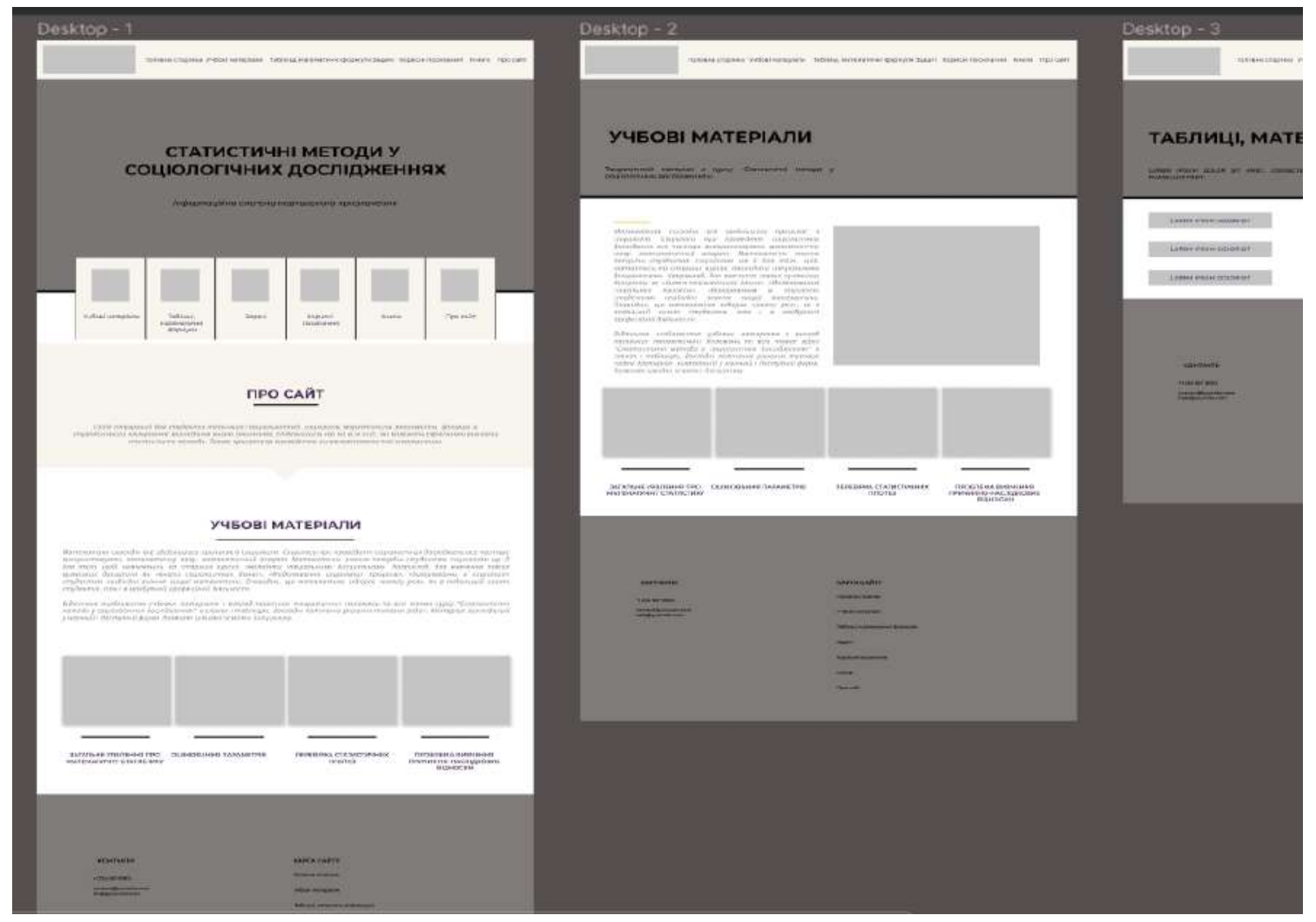

Puc. 2. Макет сайmy 


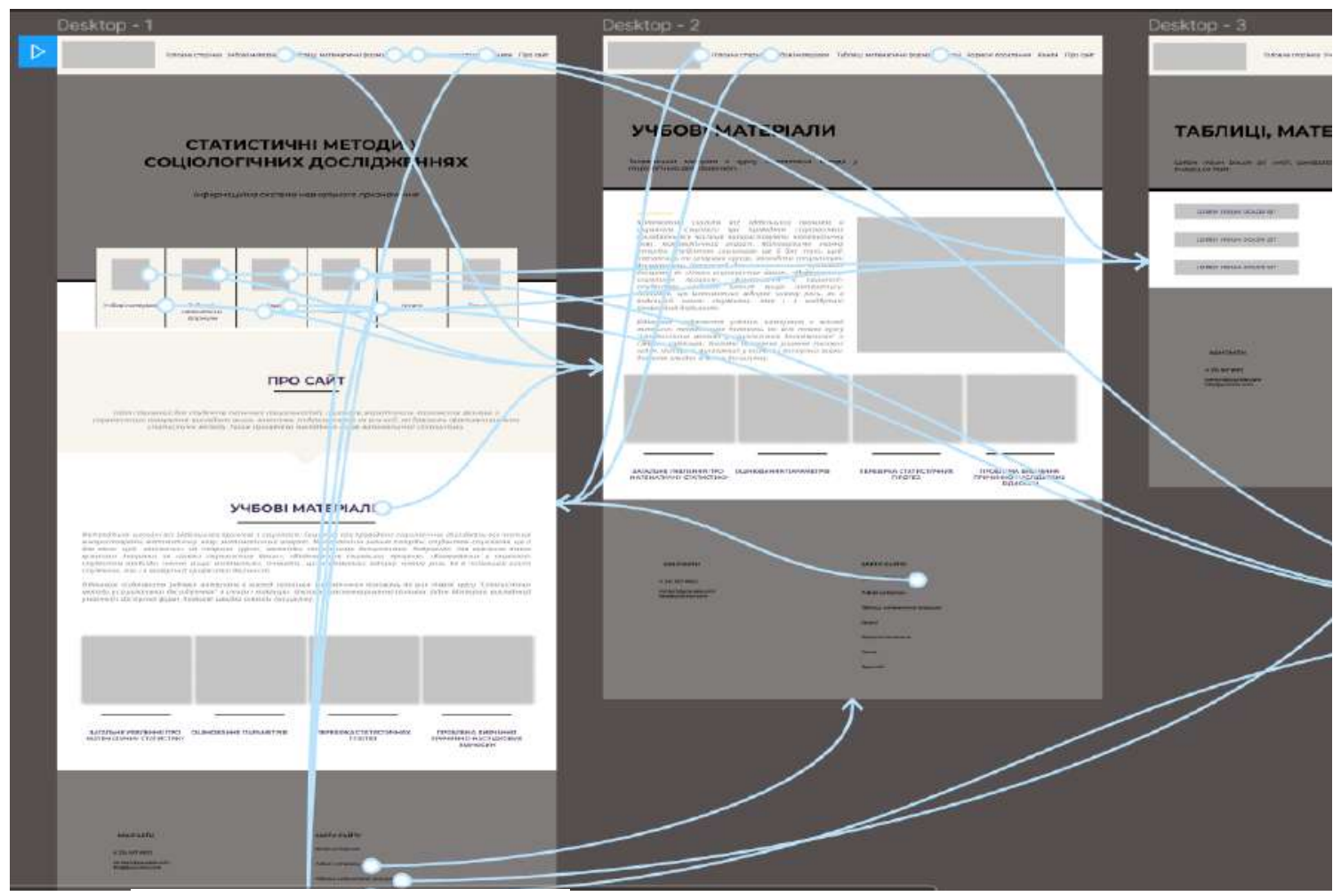

Рис.3. Анімаиія макета сайту

Підсумовуючи дане прототипування хочеться відзначити, що Figma користується хорошим попитом. Figma дозволяє замінити стандартний набір інструментів на одну просту програму. Робочі процеси дизайнерів не повинні підтримуватися за допомогою постійної синхронізації, оновлення, інтеграції та збереження. Вони повинні просто працювати, тому що дизайнеру важливі швидкість роботи над проєктом і комунікація в процесі.

При розробці інтерфейсу ми дотримувалися цілісності стильового оформлення. Сайт має єдину кольорову гаму, своєрідне стильове оформлення, яке сприймається як візитна картка сайту.

Всі сторінки сайту оформлені 3 використанням єдиних дизайнерських елементів (рис.4). Ми досягли єдності фірмового стилю і переконливого сприйняття сторінок і підсайтів сайту.

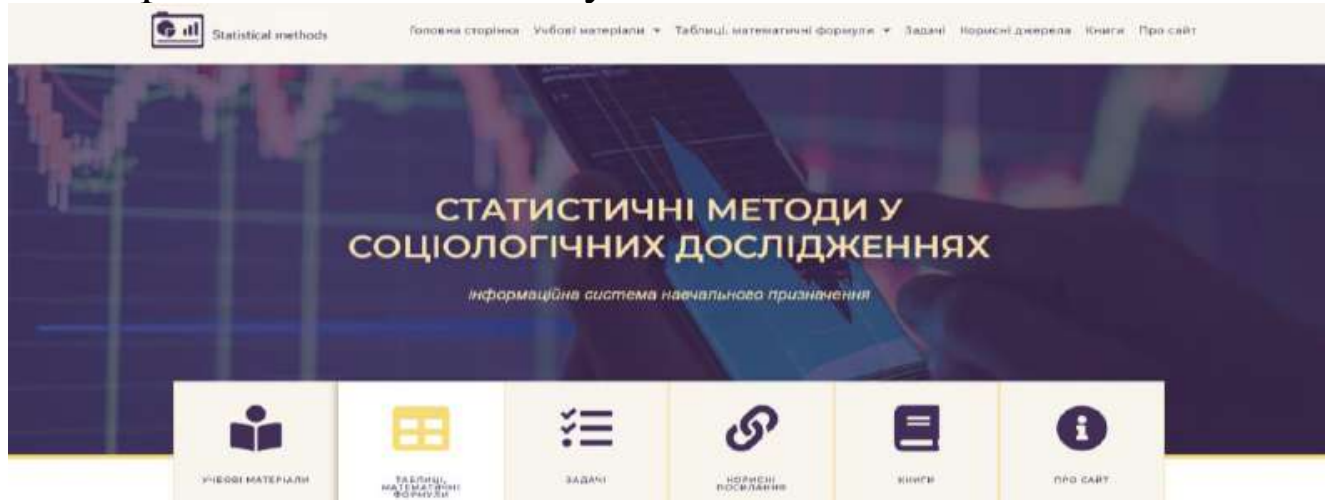

Puc. 4. Головна сторінка сайту

Також був створений дизайн мапи сайту (рис.5), необхідної для користувачів, які заплуталися в структурі проєкту або яким необхідно щось 
Журнал«Герспективитаінновації наукиљ

(Серія «Гедагогіка», Серія «ГЕихологія», Серія«Медицив»

№2(7) 2022

швидко знайти. Тут міститься просте перерахування основних розділів сайту і сторінок - необхідно для загального розуміння структури проєкту.

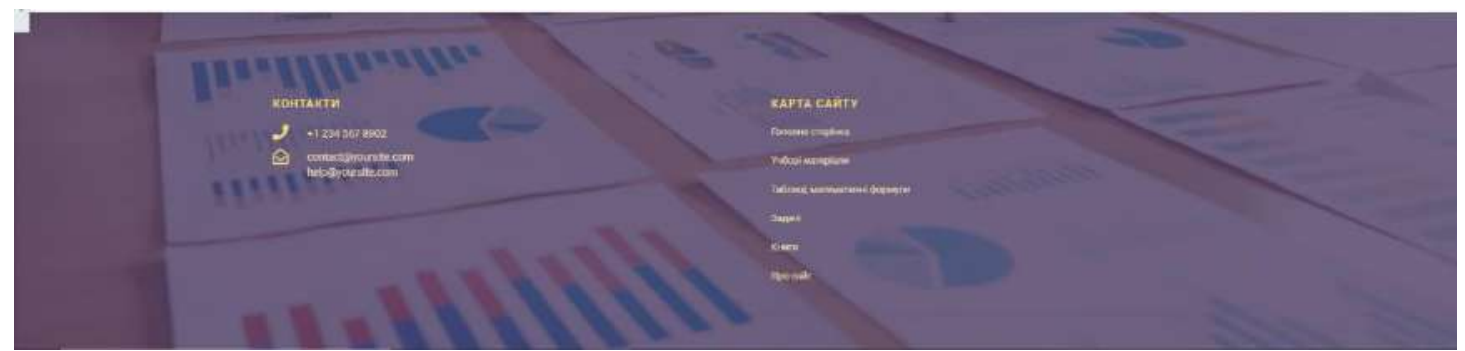

Puc.5. Mana caŭmy

Стильове оформлення інтерфейсу системи вийшло цілісним - це означає, що на всіх сторінках сайтах шрифт тексту, заголовків, посилання, інтерактивні елементи повинні виглядати в єдиному стилі. Шрифти і систему навігації (мається на увазі візуальне подання) для головної сторінки і підсторінок вибирали одні і ті ж, щоб обраний стиль був скрізь впізнаваний і всім зрозумілий (рис.6).
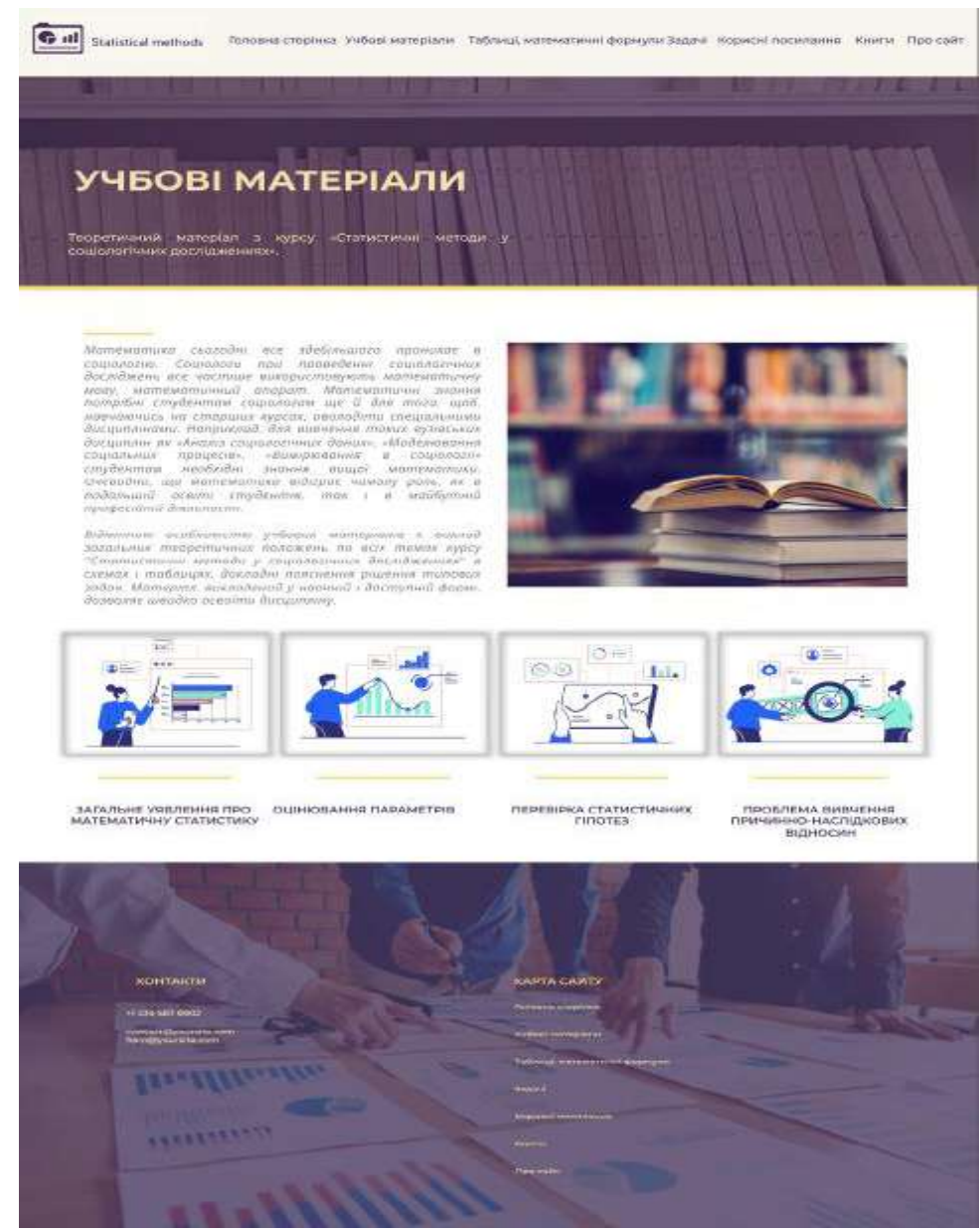

Рис.6 Одна з підсторінок системи

Меню (рис.7) дає повне уявлення про зміст і структуру інтернет-ресурсу. Розділи сайту мають однозначно зручні для сприймання назви, щоб відвідувач не витрачав час на пошуки потрібної йому інформації. 


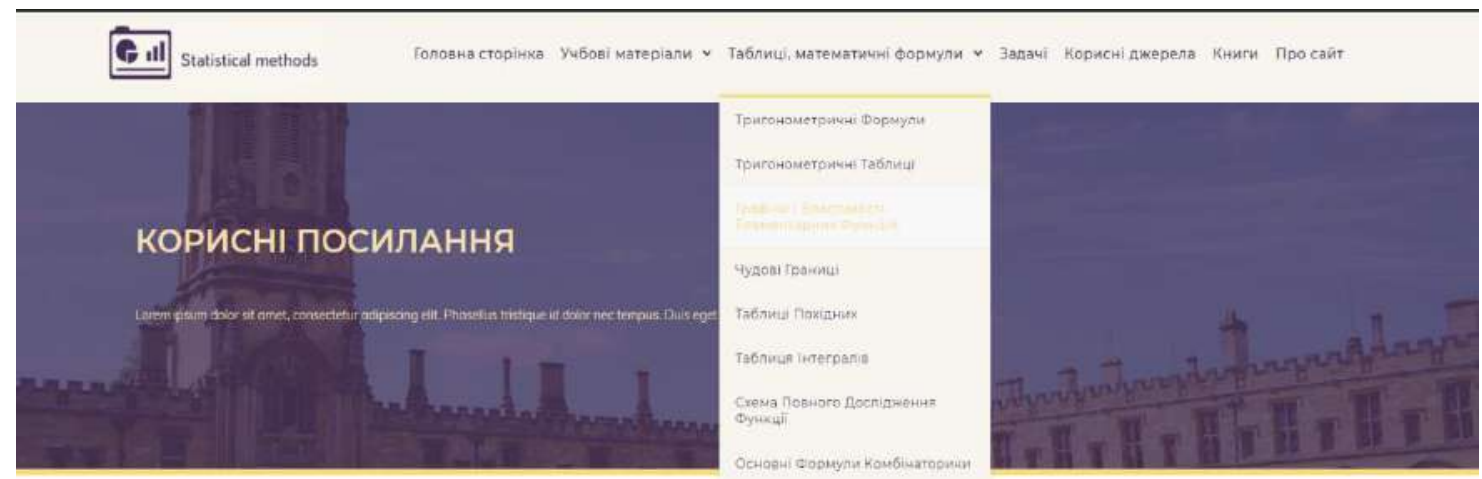

\section{Puc.7. Меню}

Висновки. У процесі дослідження були отримані наступні основні результати: досліджено контекст використання та аналоги інформаційних систем навчального призначення; проаналізувано цільову аудиторію системи;описано сценарії користувачів системи;змоделювано структуру інтерфейсу;спроєктувано прототип інтерфейсу системи;розроблено інтуїтивнозрозумілий інтерфейс інформаційної системи навчального призначення за допомогою якого користувач може отримати чіткий зворотний зв'язок, щоб зрозуміти які дії йому доступні і як їх можна вибрати або скасувати, якщо результат не виправдовує його очікування.

\section{Лimepamypa:}

1. Цільова аудиторія, цільовий ринок, сегментація - розбираємося з поняттями https://marketing-course.ru/target-audience/

2. Структура сторінки сайту http://cccp-blog.com/sozdanie-saytov/struktura-stranicy-sajta

3. Візуальна ієрархія сайту https://tilda.education/articles-visual-hierarchy

4. Що таке структура сайту і як створити https://ru.weblium.com/blog/struktura-saitachto-eto-kak-sozdat/

5. Елементи розробки веб-сайтів https://cmsmagazine.ru/journal/items-elements/

6. Прототипування для менеджерів https://dou.ua/lenta/articles/prototyping-for-managers/

7. Як створити прототип сторінок для розробки сайту https://texterra.ru/blog/kak-sozdatprototip-sayta-chtoby-on-rabotal-na-prodazhi.html

8. Walker, M., Takayama, L., \& Landay, J. A. (2002). High-Fidelity or Low-Fidelity, Paper or Computer? Choosing Attributes when Testing Web Prototypes. Proceedings of the Human Factors and Ergonomics Society Annual Meeting, 661-665

9. Figma 3.0! Стилі, прототипування і дизайн в масштабі. URL: https://ux.pub/figma-30-stili-prototipirovanie-i-dizajn-v-masshtabe/

10. Що таке figma: можливості та принципи роботи. URL: https://skillbox.ru/media/ design/chto_takoe_figma/

11. Прототипування в figma. URL: https: // https: //figma.info/blog/articles/2019-04-22prototipirovanie-v-figma.html

12. Прототипування в figma. URL: https://vc.ru/design/64379-prototipirovanie-v-figma

13. В. В. Бондарева. Вплив колірного рішення і иі-дизайну на конверсії сайту https://elibrary.ru/download/elibrary_35006308_58130776.pdf

14. Каспер системс [Електронний ресурс]. - Режим доступу: https://www.kasper.by/blog/ chto-takoe-ux-i-ui-dizain 
15. Купер, А. Інтерфейс. Основи проєктірованія взаємодії / Алан Купер, Роберт Рейман і ін. - С-Пб: Пітер, 2017. - 720 с.

16. Брусенцова, Т. П. Проектування інтерфейсів користувача: посібник для студентів спеціальності 1-47 0102 «Дизайн електронних і веб-видань» / Т. П. Брусенцова, Т. В. Кішкурно. - Мінськ: БГТУ, 2019. - 172 с.

17. Д.А.Шевченко, Ю.В. Локтюшіна. Ефективність веб-сайтів вищих навчальних закладів. Методика оцінки конкурентоспроможності сайту вузу в Інтернет - М :. ННОУ «МИПК», 2014. - 141с.

18. К. Микуленко, М. Шерман, О. Гнєдкова. Розроблення прототипу інформаційної системи навчального призначення «Статистичні методи у соціологічних дослідженнях». «Перспективи та ііновації науки», №5(5) 2021, с. 478-491

\section{References:}

1. Cil'ova auditorija, cil'ovij rinok, segmentacija - rozbira€mosja z ponjattjami [Target audience, target market, segmentation - we understand the concepts].marketing-course.ru Retrieved from https://marketing-course.ru/target-audience/ [in Ukrainian].

2. Struktura storinki sajtu [The structure of the site page] cccp-blog.com Retrieved from http://cccp-blog.com/sozdanie-saytov/struktura-stranicy-sajta [in Ukrainian].

3. Vizual'na ierarhija sajtu [Visual hierarchy of the site] tilda.education Retrieved from https://tilda.education/articles-visual-hierarchy [in Ukrainian].

4. Shho take struktura sajtu i jak stvoriti [What is the structure of the site and how to create] ru.weblium.com Retrieved from https://ru.weblium.com/blog/struktura-saita-chto-eto-kak-sozdat/ [in Ukrainian].

5. Elementi rozrobki veb-sajtiv [Elements of website development].cmsmagazine.ru Retrieved from https://cmsmagazine.ru/journal/items-elements/ [in Ukrainian].

6. Prototipuvannja dlja menedzheriv [Prototyping for managers].dou.ua Retrieved from https://dou.ua/lenta/articles/prototyping-for-managers/ [in Ukrainian].

7. Jak stvoriti prototip storinok dlja rozrobki sajtu [How to create a prototype of pages for site development]. texterra.ru Retrieved from https://texterra.ru/blog/kak-sozdat-prototip-saytachtoby-on-rabotal-na-prodazhi.html [in Ukrainian].

8. Walker, M., Takayama, L., \& Landay, J. A. (2002). High-Fidelity or Low-Fidelity, Paper or Computer? Choosing Attributes when Testing Web Prototypes. Proceedings of the Human Factors and Ergonomics Society Annual Meeting, 661-665

9. Figma 3.0! Стилі, прототипування і дизайн в масштабі. URL: https://ux.pub/figma-3-0stili-prototipirovanie-i-dizajn-v-masshtabe/

10. Shho take figma: mozhlivosti ta principi roboti. [What is figma: opportunities and principles of work]skillbox.ru Retrieved from https://skillbox.ru/media/design/chto_takoe_figma/ [in Ukrainian].

11. Prototipuvannja v figma [Prototyping in figma]. figma.info Retrieved from https: // https: //figma.info/blog/articles/2019-04-22- prototipirovanie-v-figma.html [in Ukrainian].

12. Prototipuvannja $\mathrm{v}$ figma [Prototyping in figma].vc.ru Retrieved from https://vc.ru/design/64379-prototipirovanie-v-figma [in Ukrainian].

13. Bondareva, V. V. Vpliv kolirnogo rishennja i ui-dizajnu na konversiï sajtu [The influence of color and ui-design on the conversion of the site].elibrary.ru Retrieved from elibrary.ru https://elibrary.ru/download/elibrary_35006308_58130776.pdf [in Ukrainian].

14. Kasper sistems [Casper Systems]. www.kasper.by Retrieved from: https://www.kasper.by/blog/ chto-takoe-ux-i-ui-dizain [in Ukrainian].

15. Kuper, A. (2017). Interfejs. Osnovi pro€ktirovanija vza€modiï [Interface. Fundamentals of interaction design]. S-Pb: Piter [in Ukrainian].

16. Brusencova, T. P. (2019). Proektuvannja interfejsiv koristuvacha: posibnik dlja studentiv special'nosti 1-47 0102 «Dizajn elektronnih $i$ veb-vidan'» [Design of user interfaces: a guide for students majoring in 1-47 0102 "Design of electronic and web publications"]. Mins'k: BGTU [in Ukrainian]. 
17. Shevchenko, Ju.V. (2014). Loktjushina. Efektivnist' veb-sajtiv vishhih navchal'nih zakladiv. Metodika ocinki konkurentospromozhnosti sajtu vuzu v Internet [Effectiveness of higher education websites. Methods for assessing the competitiveness of the university website on the Internet]. M .: NNOU «MIPK» [in Ukrainian].

18. Mikulenko, K, Sherman, M., Gnedkova, O. (2021). Rozroblennja prototipu informacijnoï sistemi navchal'nogo priznachennja «Statistichni metodi u sociologichnih doslidzhennjah» [Development of a prototype of an educational information system "Statistical methods in sociological research"]. Perspektivi ta iinovaciï nauki - Prospects and innovations of science, 5(5) 2021, 478-491 [in Ukrainian]. 